On the Development of Amphioxus lanceolatus.

By A. Kovalevsky.

The knowledge of the development of Amphioxus has certainly hitherto been one of the most important desiderata of science. Hence the investigations of M. Kovalevsky, incomplete as they may be, and doubtful as may be some of his interpretations, are certainly worthy of the greatest attention.

The egg of Amphioxus is formed of a vitellus, surrounded by its vitelline membrane. This vitellus has the appearance of an emulsion of fatty corpuscles, and the germinal vesicle seems to be wanting in it at the period of its maturity.

The segmentation is complete and proceeds with great regularity. As soon as repeated division has brought the number of segments to thirty-two, we see in the interior of the ovule a cavity homologous with the so-called cavity of Von Baer. Six or eight hours after deposition the blastoderm presents at one point of its surface a slight depression, which gives the germ approximately the form of a hemisphere. This depression, increasing by degrees, soon causes a restriction of the cavity of segmentation, which finally presents only the appearance of a thin clear layer interposed between the two cellular layers of the blastoderm. We may note, at present, that the cæcal cavity formed by the depression just described must be regarded as the primitive nutritive cavity, and that its single aperture will afterwards become the anus. We may also remark that the interior cellular layer represents the wall of the intestine, and that the cavity of segmentation becomes transformed into the perivisceral cavity.

After the phase just described, the outer blastodermic layer becomes covered with vibratile cilia, and the embryo begins to turn slowly upon itself. In this state the embryo quits the egg, and at the same time its movement of rotation becomes more intense.

A couple of hours after exclusion the wide aperture, which places the primitive alimentary cavity in communication with the outer world, begins to narrow, in consequence of a multiplication of the surrounding cells. At the same time the embryo becomes lengthened, and henceforward presents the appearance of an elongated cylindrical larva.

Upon this free larva there then makes its appearance a median dorsal furrow, the margins of which, rising by degrees, finally unite. Immediately after these dorsal ridges, some laminæ, destined to be transformed into lateral muscles, make their appearance. On the following day a dorsal cord may already be distinguished below the medullary tube. At the same time the mouth is formed at the anterior extremity, as an aperture which penetrates from the outer surface to the digestive sac. About the same period of larval life there appears in the anterior part of the body a sort of notch, which is soon covered with vibratile cilia, and constitutes the olfactory organ.

In the succeeding phase appear the branchiæ and the problematic gland (liver?). The former are produced in a manner very analogous to that in which we have seen the mouth to be formed: 
on the ventral margin of the body of the animal the wall of the body becomes soldered to that of the digestive cavity, and pierced by an aperture representing the first branchial fissure. The second and third fissures are formed in precisely the same manner.

At this period also the heart makes its appearance at the ventral part, and contracts slowly. From this moment each cell of the epidermis bears a single vibratile cilium in place of the large bundle of cilia which it previously displayed.

In the course of development the number of branchial fissures increases in consequence of the division of the first-formed fissures; then the chitinous skeletons of the branchiæ and various other organs appear. From each side of the body proceeds a fold of skin, which runs to meet the opposite fold and to unite with it on the ventral line-except at one point which will represent the abdominal pore.

Lastly, the author believes he has ascertained that the terminations of the nerves of the skin are histologically continuous with the cells of the epidermis.-Bibl. Univ. October 25, 1866, Bull. Sci. pp. 193195 (abstract of the original Russian paper).

\section{Alleged Discovery of an Ancient Human Skull in California.}

Accounts have recently been going the round of the press, of the discovery of a human skull in or beneath certain volcanic deposits in California, which has attracted much attention from the various ages that have been assigned to it. The facts of the case, so far as they have reached us from authentic sources, are as follows. The skull in question is alleged to have been found at a depth of 153 feet, in a shaft sunk in the consolidated volcanic ash, known locally as " lava," near Angel's Camp, in Calavaras county. Five beds of this consolidated ash were passed through, separated by beds of gravel.

The skull was found by a miner, and it soon came into the hands of Prof. J. D. Whitney, State Geologist of California, who visited the locality and investigated the matter as far as was then possible; but, owing to the presence of water and the stoppage of work in the shaft, the examination was not fully satisfactory. He has made a preliminary statement before the California Academy of Natural Sciences, but defers any extended notice until the subject can be investigated with more completeness and accuracy. He thinks the skull was found in the position claimed, and will investigate the subject when the water is pumped out of the shaft and work resumed, which is expected to be done soon.

The precise age of the beds in question is as yet uncertain. In the ' Geology of California,' Prof. Whitney considers that the eruption of the great mass of volcanic materials on the western slope of the Sierra Nevada began in the Pliocene age, and that it continued into the Postpliocene, and possibly to comparatively modern times. The alleged position of the skull is a lower one than any in which the remains of the mastodon have there been found; and therefore the question of its authenticity becomes a very important one; and when the more 


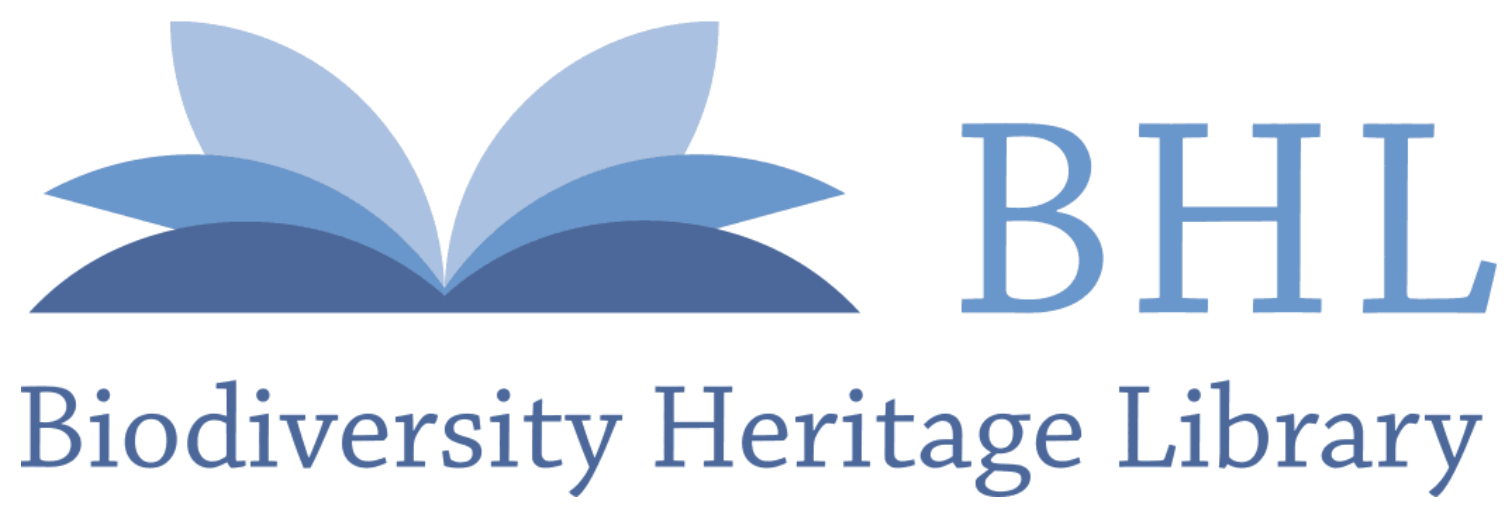

Kovalevsky, A. 1867. "On the development of Amphioxus lanceolatus." The Annals and magazine of natural history; zoology, botany, and geology 19, 69-70.

View This Item Online: https://www.biodiversitylibrary.org/item/72153

Permalink: https://www.biodiversitylibrary.org/partpdf/60981

\section{Holding Institution}

University of Toronto - Gerstein Science Information Centre

\section{Sponsored by}

University of Toronto

\section{Copyright \& Reuse}

Copyright Status: NOT_IN_COPYRIGHT

This document was created from content at the Biodiversity Heritage Library, the world's largest open access digital library for biodiversity literature and archives. Visit BHL at https://www.biodiversitylibrary.org. 